\title{
Diversity as a Critical Element in Stimulating the Role of Technical Universities in the Regional Economy
}

\author{
Marina van Geenhuizen*, Danny Soetanto* and Peter Nijkamp**
}

\begin{abstract}
Universities are increasingly seen as important players in the regional economy, among others through their contribution to the rise of new high-technology companies and mechanisms of knowledge transfer. Regional-economic development and the creation of academic research clusters are becoming more and more mutually intertwined dynamic forces. In this paper, we will offer some background observations, describe some empirical developments concerning the desired and actual growth of spin-off companies from universities, and provide some strategic policy lessons. The focus of analysis is on differences in growth rate of incubators in a comparative study across the developed world and on differences in growth rate between spin-off companies in a local study, i.e. concerning Delft University of Technology in Delft in the Netherlands. The overall conclusion is that diversity matters in many ways in a positive sense For example, diversity in stakeholders in the incubation initiative, diversity in types of target companies in incubation programs, and diversity in networks through which knowledge flows tend to enhance growth of spin-off companies.
\end{abstract}

JEL Classification: O32, O33, R11

Keywords: Technical Universities, Spin-off Companies, Incubators, Personal Knowledge Networks, Diversity, Delft University of Technology

\section{The Changing Scene of Universities}

Universities have always been - and will continue to be - a place where new scientific knowledge is discovered and taught to students. Until a few decades ago, the idea was that a science-driven education would create good students who would apply the academic knowledge after the completion of their studies. Universities were more or less solid bastions of independent research, not directly engaged in real world applications.

This traditional view on academic institutions is clearly reflected in various regional impact studies of universities where the main regional-economic effects of universities were estimated on the basis of multiplier studies related to expenditure patterns of universities' staff and students [1]. The commercial and industrial ('generative') effects, like the ones derived from knowledge valorization, were often overlooked. The reason why cities and regions were keen on establishing an academic institution in their territory was mainly stemming from the local prestige of an institute for higher education and advanced research. In cases where local business helped to finance an academic knowledge institute, an expected

* Delft University of Technology, Faculty of Technology, Policy and Management

** Free University Amsterdam, Department of Regional Economics

Received: 31 December 2006 Accepted : 15 October 2007

(C) 日本地域学会（JSRSAI） 2007 
indirect benefit (e.g., acquisition of good students) was an important motive. Academic freedom was nevertheless always seen as a 'Rubicon' that should not be violated.

In recent years, we have witnessed a much more direct involvement of academic institutions with commercialized knowledge acquisition and technology transfer [20]. Universities are no longer an oasis in a rapidly changing environment; they follow a tidal movement in response to the request of society to offer not only societal relevance but also socio-economic and technological returns ('value for money'). The margins between the university systems and the commercial system sometimes have become fuzzy and sometimes very thin [16] [35]. When Harvard discussed in 1980 the idea to launch a biotechnology firm in order to create a commercial market value for one of its staff members, the New York Times (1980:34) wrote a devastating commentary and concluded: "Universities that seek a legitimate return from the ideas and inventions of their faculties must be careful not to lose their academic souls" [26]. Nevertheless, at present, not only most US universities but almost all universities have moved their mission and orientation towards the commercial and technology sector. The reasons for this development are manifold:

- A shortage of funding from the side of public bodies.

- Accountability to policy-making bodies and the public at large ('valorization').

- Insufficient usage of publicly financed research at universities for commercial applications in an age where competition in a global world becomes fierce ('technology transfer gap').

- Reduction in basic research in large corporate firms with the necessary consequence that publicly financed universities are pushed in this vacant positions.

- Far reaching changes in the research system itself (e.g. biomedical technology) where academic inventions in various key sectors incorporate a potentially high economic value which through Intellectual Property Right (IPR) regulations may need to be protected and through subsequent licensing may be translated in monetary revenues [13].

- The rise of a knowledge-based society causing academic institutions to be much more strategic spearheads of accelerated economic growth, with the consequence that science -based clusters (e.g., science parks) around universities are arising.

Regional-economic development and the creation of academic research clusters are becoming more and more mutually intertwined dynamic forces [1] [11]. In this paper we will offer some background observations, describe some empirical developments concerning the desired growth of spin-off companies from universities, and provide some strategic policy lessons and future research paths.

\section{Universities as Wealth Creators}

Universities have a longstanding tradition as a knowledge creator, but not as a wealth creator. As indicated above, this position of universities has changed. Indeed, universities are often nowadays involved in the creation of spin-offs, i.e. new companies created as a result of an academic research environment with the aims to use new knowledge developed and owned by the university (or its staff) in a commercial setting. This rather new phenomenon which started perhaps modestly after World War II, grew in the early 1980s [7] and has now fully entered the research policy of modern universities. Consequently, university 


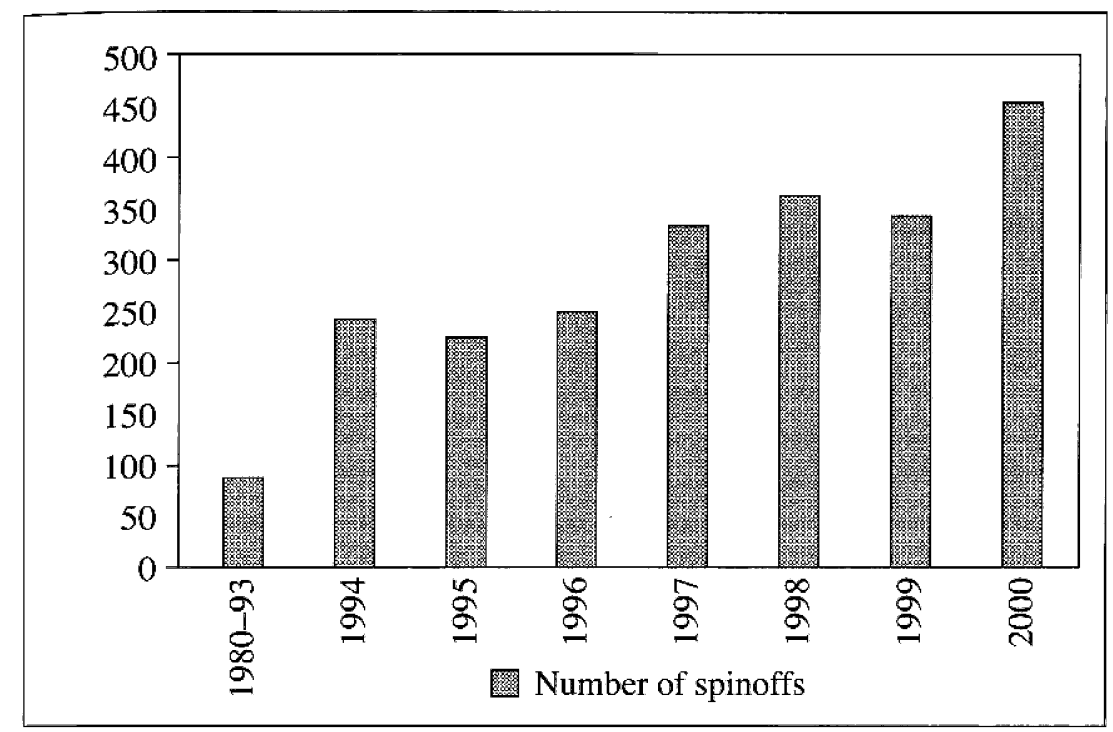

Note: The figure for $1980-93$ is the average annual number of spinoffs per year; for all other years, the figure is the actual number of spinoffs per year.

Source: Based on data contained in Pressman, L. (ed.) (2002), AUTM Licensing Survey: FY 2000, Northbook, IL: Association of University Technology Managers.

Figure 1. Number of spin-offs from American academic institutions, from 1980-2000 Source: [42, p. 57]

policy is nowadays full of talk about invention disclosures, venturing, patenting and licensing [42]. And indeed we observe a structural growth in the number of spin-offs by universities (see Figure 1).

In the USA, the passage of the Bay-Dole Act (1980) has been of decisive importance. This law and its follow-on rights (1984) gave universities much more flexibility in licensing and commercializing federally founded research inventions, by stimulating the founding of spin-off companies serving to license and commercially develop these technological discoveries. The Act also stimulated SME's to participate in publicly founded R\&D initiatives. From a regional-economic development perspective, the university became potentially a very important player [40] [43].

There are several reasons why a strong orientation of a region (or nation) to an advanced or academic knowledge institution has many potential benefits. Shane [42] distinguishes the following elements :

- University spin-offs create local economic development (through innovation, application of advanced technology and stimulation of an R\&D climate).

- Spin-offs generate economic value (through financial assets), accelerate access to commercialized knowledge and the creation of a business climate.

- Spin-offs create employment in terms of skilled labor, but also indirect labor market effects.

- Spin-offs induce private investments in university technologies (through commercial initiatives such as patenting and licensing). 
- Spin-offs call for new research initiatives (through a successful commercialization of an invention there will be a call for new inventions in a competitive environment).

- Spin-offs are breeding ground for young talent (e.g., by offering internships and training facilities to students).

It is thus evident that modern universities are nowadays operating in a completely different force field compared to a few decades ago. Not only has the industry-university interface shown a dramatic change, the role of the public sector has also changed. Two aspects are noteworthy here. First, the orientation of university research towards market value calls for a new regulatory system (witness the Bay-Dole Act) in which the new force field of publicly founded research institutions is set out. And second, the development of a successful spin-off policy puts high demands on local and regional public authorities to orient regional development initiatives (e.g., infrastructure, suprastructure, incubators) towards promising $R \& D$ initiatives geared to the application of new knowledge in the area concerned. Such a policy may be relatively general in aim by encompassing different high-technology areas, like micro-electronics, optronics, sensor technology, nanotechnology, informatics and computational science and biotechnology, or specifically focusing on one or two related areas like biotechnology [13].

University-industry-government relations, also named Triple Helix [10] [27], can be seen as adaptive networks that have changed over time in response to different dynamics in their environment. The networks fulfill three core functions, i.e. knowledge production, wealth generation and governance (control). One of the clearest changes over time is a blurring of the edges between the functions of each of the three actors. Thus, in Western Europe and North America, universities have become more entrepreneurial, whereas large companies have started knowledge production-based education in campuses hosting training in specific academic fields; and governments are increasingly engaged in enhancing the knowledge-based economy by improving conditions for entrepreneurial innovation [10]. In particular, the role of universities has changed in the past decade, with additional tasks in the entrepreneurial sphere, aside from the traditional ones in education and research. Also, universities have adopted more societal responsibilities, such as in solving particular problems in the regional economy and society [5] [6]. There seems no end in the above changes, meaning a continued integration and hybridization of functions in the coming years, although the starting point and pace of changes may differ across countries [48]. Consequently, the university, industry (commercial sector) and government network calls for a thorough investigation. We now turn to our empirical study to show how regional (local) initiatives to nurture academic spin-off companies may differ in design and in result.

\section{Growth of Incubators : a Global Comparison of a Regional Policy Tool}

\subsection{Introduction}

We perceive incubators primarily as organizations that create a supportive environment for companies to get started and to survive the first years. Incubator organizations as part of a university usually employ one or a few buildings in which they offer cheap and flexible rooms and supporting (secretarial) services, while some offer rooms spread over various on campus faculty buildings. A new development is the networked incubator [3], particularly 
the non-physical version or virtual incubator, merely working as an electronic network organization [22]. By nature, incubators support start-ups on a temporary basis, e.g. three or four years.

\subsection{Expectations about growth patterns}

In this section we examine six factors that may influence the growth rate of incubators, i.e. variety in the involvement of stakeholders, the overall incubation strategy and the model of support, the age of the incubator as an organization, the entrepreneurial culture in the area and the level of urbanization of the region.

Incubators differ in the kind of stakeholders involved in the establishment and management, leading to differences in creative atmosphere and richness of resources. We may observe incubators mainly organized by a university or research institute, as well as incubators that internalize the triadic relationships between the university, government and industry and the hybridization of their roles [10] [27]. The involvement of different stakeholders as opposed to the involvement of merely the university - implies a potential access to more varied networks and resources and the ability to better respond to heterogeneity among incubated start-ups [3] [9] [32]. Thus, we may assume that the multiple stakeholder model brings about a more dynamic growth compared with the single stakeholder model.

The next two institutional factors represent choices made by incubator organizations and their stakeholders, that is, the overall incubation strategy and the model of support. Hannon and Chaplin [21] identify two incubation strategies in the United Kingdom, i.e. pure incubators and flagship models. The pure incubators are traditionally established by universities and seek to exploit university potentials by nurturing firms that commercialize research results. The flagship model, on the contrary, originates also from initiatives by local or regional governments, or real estate developers, and tends to be more profit-oriented due to higher initial investment and running costs. More recently, besides the flagship strategy, incubators are emerging that also employ a certain level of profit-seeking and invite start-ups from outside the university to join the incubation program. We expect the latter incubators to grow faster than the traditional ones, because they face an inflow of more varied knowledge and face participation in more diversified networks in resource gathering. With regard to the model of support, we argue the following. Conventional support mainly deals with the provision of tangible assets, e.g. room and basic office services, laboratory facilities and financial support. However, there has been an evolution in the recent past, from conventional to added-value support; the latter including support in connecting startups to relevant networks, like business angel networks, and new methods in business mentoring and training to increase the spin-offs capability to survive, like training the entrepreneurs' capability to develop strategic thinking, establish and maintain networks, and negotiate with and convince potential customers. Value-added support may also include active help in exit strategies. We may assume that an emphasis on value-added support accelerates the growth of incubated start-ups, thus increasing the number of incubated startups per year.

In managing an incubator, experience and professionalism in selection, monitoring and coaching of start-ups seem critical [42] [43]. A study in the US shows that it takes several 
years for incubators to become mature, in terms of gaining the capability to organize themselves efficiently, access the most fertile networks and produce independent and viable firms on a continuous basis [31]. Although learning is not a linear process, it increases with age. Accordingly, we may assume that the growth of incubators is stronger with increasing age. With regard to influence of entrepreneurial culture, we argue the following. An important dimension of entrepreneurial culture is uncertainty avoidance [23]. Countries facing high levels of uncertainty avoidance generally show a tight regulation of entrepreneurship and an accepted resistance to enter new, risky avenues. By contrast, in countries with low levels of uncertainty avoidance, there is room for differentiation, experimentation and risk-taking in business operations. The latter entrepreneurial climate is also believed to stimulate incubator organizations to be more active and creative in searching for new possibilities of supporting their ventures. All this may lead to a more dynamic growth of incubators.

The last factor to be considered here is concerned with differences in the urban environment of the incubators, particularly the spatial concentration of human capital and knowledge. Jacobs [24] draws attention to metropolitan cities in attracting and mobilizing talented and creative people. In a similar vein, a growing stream of more recent research has focused on factors that attract talented people [12] [17]. This has led to the understanding that metropolitan cities providing a high diversity in amenities, entertainment, art facilities and lifestyle, have important advantages in attracting and keeping talented and creative people. In such an environment there is already a strong entrepreneurial community with experience to select the best projects and allocate appropriate resources. Therefore, we assume that incubators in metropolitan cities enjoy the benefits of a large pool of talented entrepreneurs and knowledge advantages, and expect these incubators to grow relatively fast; this in contrast with incubators in rural areas and peripherally located regions.

Note that - with regard to the model of incubators - capacity indicators like size of the buildings and budgets of incubator organizations remain beyond our analysis because of we focus on strategic factors. For the same reason, operational details like access criteria and time-length of incubators' support fall outside the study.

\subsection{A differentiated growth of incubators}

The selection of incubators in this study took three specific requirements into consideration. First, to be a technology-related incubator ; this type of incubators supports mainly technology-based start-ups and employs institutional links with and/or is located close to a university or research center. Secondly, to face a similar time-frame; incubators in the 1980s cannot be compared with those in the 1990s because of the potential influence of different macro-economic factors. And thirdly, to face particular characteristics in one (or more) of the six determining factors of growth of incubators. Our main data sources were paper journals, conference proceedings, annual reports of incubators, and incubators' websites. As a result of the above selection process, we established a set of 40 incubators (base population). For various testing procedures we have drawn 10 random samples from this population. 
The data concerning the incubators are largely qualitative in nature. Hence, a special statistical technique is required to arrive at testable solid results. We made use of rough set analysis to identify the strength of the above six factors in explaining differences in growth of 40 incubators in various developed countries. Growth, measured as an average number of new spin-offs (entrants) per year in the years 1998-2002, varied between -3.0 and +7.0 . The frequency distribution allowed for a division of the incubators into two classes, i.e. those experiencing a relatively strong growth and those experiencing a relatively weak growth.

Rough set analysis enables the transformation of an imprecise or incomplete (fuzzy) collection of data, both quantitative and qualitative, into structured knowledge [36]. Unlike conventional methods that are based on statistical assumptions, this analysis makes the only assumption that the value of the determining factors can be categorized. In particular, rough set analysis is able to incorporate different measurement scales and different degrees of measurement accuracy. In the past few years various studies have proved to be successful in using rough set as a tool of analysis in different areas [18] [33] [34] [45] [46].

In rough set analysis, the dependent variable is named the decision attribute (in our study, growth of incubators) and the independent (explanatory) variables are named condition attributes (in our study, model of stakeholders' involvement, type of urban location, risk avoiding attitude, model of support, incubation strategy and age of the incubation organization). Rough set analysis is in fact a classification technique and can be seen as a kind of 'qualitative correlation analysis'. It produces a set of decision rules, presented in an "IF condition(s) … THEN decision" format. Condition attributes that are in the so-called core have the strongest explanatory power ; these are indispensable in explaining the variation in the decision attribute. All other condition attributes appear at a lower frequency in the rules. In general, a high frequency rate of individual condition attributes in the decision rules means that these attributes stand out in a more pronounced way than others. In addition, the coverage indicates the strength of the rules based on the rate in which objects in a subset with the same decision attribute support the decision rule. In our study, the rough set estimations were conducted using ROSE2 software [37] (note 1).

We analyzed the 10 samples (each of approximately 25 incubators) derived from the base population of 40 incubators. Seven strongest rules could be identified concerning a weak growth and five strongest rules could be identified concerning a strong growth (Table 1). We used two measures in exploring the explanatory power of the rules, (1) the frequency of individual condition attributes in the strongest rules and (2) the frequency of the strongest rules in the samples. With regard to the first measure, the frequency of each condition attribute in the strongest rule was divided by the total number of strongest rules in that class of growth (weak or strong). For example, regarding a weak growth, the model of stakeholders' involvement (C1) faces a frequency rate of $43 \%\left(3 / 7^{*} 100 \%\right)$.

On the basis of these outcomes, it appears that various condition attributes have a strong classificatory power :

1. Conventional support (C4) for weak growth (57\%); this confirms our idea of a modest impact of support that is merely tangible and fails to train individual start-ups in strengthening business capabilities ;

2. Multiple stakeholders' involvement (C1) for a relatively strong growth (60\%); this also 
Table 1. Frequency of individual condition attributes in the strongest rules*

\begin{tabular}{|c|c|c|c|c|c|c|}
\hline $\begin{array}{l}\text { Weak growth } \\
\text { (strongest rules) }\end{array}$ & $\mathrm{C} 1$ & C2 & C3 & $\mathrm{C} 4$ & C5 & C6 \\
\hline $\begin{array}{c}\text { Frequency of } \\
\text { appearance } \\
(\%)\end{array}$ & $\begin{array}{l}43.0 \\
(3 / 7)\end{array}$ & $\begin{array}{l}29.0 \\
(2 / 7\end{array}$ & $\begin{array}{l}43.0 \\
(3 / 7)\end{array}$ & $\begin{array}{l}57.0 \\
(4 / 7)\end{array}$ & $\begin{array}{l}43.0 \\
(3 / 7)\end{array}$ & $\begin{array}{l}14.0 \\
(1 / 7)\end{array}$ \\
\hline $\begin{array}{c}\text { Strong growth } \\
\text { (strongest rules) }\end{array}$ & $\mathrm{C} 1$ & $\mathrm{C} 2$ & C3 & $\mathrm{C} 4$ & C5 & C6 \\
\hline $\begin{array}{c}\text { Frequency of } \\
\text { appearance } \\
(\%)\end{array}$ & $\begin{array}{c}60.0 \\
(3 / 5)\end{array}$ & $\begin{array}{l}60.0 \\
(3 / 5)\end{array}$ & $\begin{array}{l}20.0 \\
(1 / 5)\end{array}$ & 0 & $\begin{array}{l}40.0 \\
(2 / 5)\end{array}$ & $\begin{array}{l}20.0 \\
(1 / 5)\end{array}$ \\
\hline
\end{tabular}

*Condition attributes

C1: Stakeholders' involvement (1: single stakeholder involvement ; 2 : multiple stakeholder involvement)

C2: Position in the urban system (1: metropolitan areas 2 : non-metropolitan areas/peripheral)

C3: Uncertainty avoiding attitude (index) (1: low; 2 : high)

C4 : Model of support provided by incubators (1: conventional ; 2 : value added)

C5: Incubation strategy (1: research commercialization; 2: profit-focused)

C6: Age of the incubator organization $(1:<5$ years old;

$2: 5$ years old)

Decision attribute

D : Average annual growth (1: relatively weak $(\leq 1.25) ; 2$ : relatively strong $(>1.25))$

confirms our expectations, in that the involvement of different stakeholders in steering the incubator introduces a favorable diversity of resources, including networks and knowledge flows ;

3. Location in non-metropolitan areas (C2) for a relatively strong growth (60\%) ; different from the previous outcomes, this outcome cannot confirm our expectations.

There may be three explanations for the last, unexpected, result. First, in particular metropolitan areas, living conditions may have turned into a process of decline due to diseconomies of agglomeration causing creative workers and other talented people to move to smaller cities and rural areas. Secondly, in Europe, particular non-metropolitan areas receive targeted regional development assistance from the EU and the country, causing the establishment and operation of incubator facilities to be less costly, a situation that enables the supply of a wider range and higher intensity of support to spin-offs. Third, in dense metropolitan areas the incubation process may work rather spontaneously, particularly in older city quarters on the fringe of the central business district with plenty supply of cheap accommodation, thereby reducing the role of incubators and causing them being almost redundant. With regard to the remaining attributes - risk avoiding attitude, incubation strategy, and age of the incubator organization - we note a minor importance (Table 1).

Next, we examined the pattern of strongest rules as combinations of particular condition attributes. The focus was on the frequency in which the strongest rules (top three for each 
Table 2. Frequency of appearance of the strongest rules in the 10 samples

\begin{tabular}{|c|c|c|c|}
\hline Strongest rules (a) & Frequency in the 10 samples (\%) & $\begin{array}{c}\text { Strong } \\
\text { growth }\end{array}$ & $\begin{array}{c}\text { Weak } \\
\text { growth }\end{array}$ \\
\hline C1 \& C2 & $60.0(6 / 10)$ & 3 & 3 \\
C4 \& C5 & $40.0(4 / 10)$ & 2 & 2 \\
C1 \& C5 & $30.0(3 / 10)$ & 1 & 2 \\
C1 \& C6 & $20.0(2 / 10)$ & 0 & 2 \\
C2 \& C5 & $20.0(2 / 10)$ & 2 & 0 \\
\hline
\end{tabular}

(a) C1-C6: The condition attributes (model of stakeholders' involvement, level of urbanization, uncertainty avoiding attitude, model of support, incubation strategy, and age of incubator).

sample) appear in the 10 samples. Two strongest rules appeared in more than three samples with one of them appearing in a majority of the samples (6 out of 10) (Table 2).

These rules include (1) the combination of the model of stakeholder involvement (multiple) with urban conditions (non-metropolitan areas) (C1 \& C2), and (2) the model of support provided to the start-ups combined with the type of incubation strategy (value-added support and a limited profit-focused strategy) (C4 \& C5), and refer both to strong growth.

Note that the validity of the outcomes of this analysis depends on how well the selected incubators represent the different types of incubators in developed countries. In any case, the analysis is rather robust because the prediction accuracy of the rules, measured as the share of correctly predicted cases using new samples, turned out to be around 75\% [45]. We now move to a detailed analysis of growth of academic spin-off companies, in one of the studied incubators, i.e. Delft University of Technology (in the city of Delft, the Netherlands) (Note 2).

\section{Growth of TU Delft's Spin-offs : a Local View}

\subsection{Introduction}

Delft University of Technology adopted a first policy to support academic entrepreneurship in 1998. Prior to this year, some support was given but this did not happen through an explicit policy. The initiative in 1998 was built on the national program 'Technostarters' and provided a set of support measures from which academic entrepreneurs could select dependent upon their personal needs, such as a loan (without interest) up to a maximum of $€ 16,800$, use of accommodation at the faculty and, if available, coaching by faculty members. The program did not provide room in a special incubator building. Rather, the spin-offs were dispersed in faculty buildings (laboratories) and in various business buildings hosting start-ups in the city of Delft. To strengthen the initiative in 2005, TU Delft established a close collaboration with the Municipality of Delft and set up an incubator program named YES!Delft. This new program encompasses a more comprehensive set of support measures, including room in an incubator building and additional value added support.

In the previously discussed analysis, the incubator (organization) of Delft qualified as a relatively "slow grower" in the years 1998-2002. However, we may expect that the growth of the number of entrants has increased in the following years due to various changes. In the current situation, more stakeholders are involved and the support has been extended with 
value added measures, including a higher diversity of available networks and resources.

In general, the connection between the growth of incubators in terms of numbers of new entrants and the growth of spin-offs in terms of employment lies in the fact that incubators grow more quickly if the incubated companies grow more quickly and qualify for an early exit from the incubator (shorter stay). We now turn to individual spin-offs to explore whether differences in growth can be attributed to factors representing diversity in the business environment and in socioeconomic networks.

\subsection{Assumptions Concerning Growth of Spin-offs}

On the basis of a study of the literature, we have focused on four socioeconomic aspects of knowledge networks : tightness, strength, heterogeneity and spatial proximity of network partners. Note that the literature is not conclusive on whether particular network characteristics (like rather loose relationships or a strong heterogeneity of the social background of network partners) contribute to growth. For example, some scholars adhere the idea that tight networks are beneficial for the transfer of complex and tacit knowledge, development of trust and comfort, and joint problem solving [8] [47]. By contrast, Granovetter [19] argues that loose networks cause benefits from diversity in knowledge flow and brokerage opportunities created by a lack of connections [30]. In addition, Marsden [28] shows that partners integrating different spheres of society facilitate more efficient actions than partners that are similar in background. In this latter respect, there is more or less consensus in the literature: the more heterogeneous the partners, the more variety in the resources (including knowledge) captured by spin-off companies and the better the performance.

With regard to spatial proximity in the networks, we may forward the following viewpoints. Local (regional) networks, according to proximity approaches, yields the benefits of knowledge spillovers (avoided costs of knowledge exchange) and local learning through frequent interaction in person and high levels of trust [2] [11] [25] [29]. Following Camagni [4], it seems that close proximity between spin-offs and network partners supports the gaining of new knowledge (reduction of uncertainty) thereby enhancing growth of spinoffs. On the other hand, local networks may also produce the above-indicated disadvantage of strong ties preventing new knowledge to be recognized and absorbed by the spin-offs.

Regarding the two different types of support (conventional support and value-added support combined with conventional support, as discussed in the first part of this paper) we expect that spin-offs that experience a balanced mix of conventional support and value added support grow quicker compared with spin-offs that experience merely conventional support or a poor mix. In the next section, we will explore and test the above ideas and assumptions.

\subsection{Growth of TU Delft Spin-off Companies}

We delineated the population of spin-offs of TU Delft on the basis of three criteria, i.e. located in Delft or the surrounding area, aged less than 10 years and having used at least one support measure from TU Delft. We approached all companies in this population, leading to a response rate of $67 \%$ (51 valid cases), and we collected data using a semi-structured questionnaire in face-to-face interviews with entrepreneurs. We were particularly inter- 
Table 3. Job growth of TU Delft's spin-offs in 1996-2005

\begin{tabular}{|c|c|c|}
\hline $\begin{array}{c}\text { Average annual job } \\
\text { growth (fte)* }\end{array}$ & Number of spin-offs & Percentage share \\
\hline$<0.5$ & 16 & 31.4 \\
$0.5-1.0$ & 12 & 23.5 \\
$1.00-1.5$ & 10 & 19.6 \\
$>1.5$ & 13 & 25.5 \\
\hline Total & 51 & 100 \\
\hline
\end{tabular}

*full-time equivalent.

Source: Adapted from [15].

Table 4. Problematic obstacles as perceived by entrepreneurs

\begin{tabular}{|l|l|c|c|c|}
\hline \multicolumn{1}{|c|}{ Obstacles } & \multicolumn{1}{|c|}{ Specification } & Total & \% & Rank \\
\hline $\begin{array}{l}\text { Market knowledge and } \\
\text { skills }\end{array}$ & Lack of marketing knowledge & 26 & 17.2 & 1 \\
& Lack of sales skills & 24 & 15.9 & 2 \\
& Lack of forecasting capability on future & 20 & 13.3 & 4 \\
& markets & 21 & 13.9 & 3 \\
Management & Difficulty in dealing with uncertainty & 15 & 9.9 & 6 \\
capabilities & Management overload & 16 & 10.6 & 5 \\
Market & Lack of market demand & 11 & 7.3 & 7 \\
Financial & Lack of investment capital & 7 & 4.6 & 8 \\
\hline Accommodation/ & Lack of cash flow & 5 & 3.3 & 9 \\
facilities & Lack of adequate accommodation & 4 & 2.7 & 10 \\
\hline
\end{tabular}

Source: Adapted from [15].

ested in the question to what extent growth of spin-off companies (in terms of jobs) can be explained by the three socioeconomic aspects of knowledge networks in terms of diversity in the knowledge flowing through the networks, and by various combinations of support types (conventional and value-added support).

The growth rate of spin-off companies of TU Delft is relatively modest over the past years (1996-2005) (Table 3). About 30\% of the spin-offs face a very small job growth or no growth at all (less than 0.5 jobs on average per year) while only $25 \%$ face a growth in the highest category (more than 1.5 jobs on average per year). The average growth rate among all spin-offs is 1.1 and varies between 0.0 and 6.0 jobs per year.

In a self-evaluation, the entrepreneurs identified various obstacles that have hindered their growth (Table 4). It appears that most obstacles are concerned with shortages in knowledge and skills in market issues and management. It is not surprising that lack of marketing and sales skills are the main obstacles (17 and 16\% of all obstacles), since most spin-offs evolve from an initial idea in a non-commercial setting to a profit-generating company in a competitive setting, situations in which completely different resources (knowledge and skills) are required. Similarly, the importance of the third main obstacle, the difficulty in dealing with uncertainty $(14 \%)$ can be understood by taking the shifting context 
Table 5. Variables and measurement

\begin{tabular}{|l|l|}
\hline \multicolumn{1}{|c|}{ Variables } & \multicolumn{1}{c|}{ Measurement } \\
\hline Job growth & Average annual growth of jobs in 1996-2005 (full-time equivalent). \\
\hline $\begin{array}{l}\text { Tightness of } \\
\text { relationships }\end{array}$ & $\begin{array}{l}\text { Number of existing relationships divided by the number of potential relationships. } \\
\text { The latter is calculated as the maximum number of relationships if all partners in } \\
\text { the network are connected [28] [39]. The value is between 0 and 1, with a low } \\
\text { value indicating a loose network and a high value indicating a tight network. }\end{array}$ \\
\hline $\begin{array}{l}\text { Strength of } \\
\text { relationships }\end{array}$ & $\begin{array}{l}\text { A composite indicator calculated on the basis of the average frequency of interac- } \\
\text { tion with partners and the average number of years that the relationship has lasted. } \\
\text { Following Granovetter [19]*) and Marsden and Campbel [28], the variable is the } \\
\text { added sum. Low values indicate weak relationships and high values indicate } \\
\text { strong relationships. }\end{array}$ \\
\hline $\begin{array}{l}\text { Homogeneity of } \\
\text { network } \\
\text { partners (index) }\end{array}$ & $\begin{array}{l}\text { Scores on a homogeneity index. The scores are calculated on the basis of the } \\
\text { square of the number of partners with a similar social background divided by the } \\
\text { total number of partners, basically like Scholten [41]. We used three different } \\
\text { backgrounds, i.e. university, large company and small company. A high value } \\
\text { indicates a dominance of a similar background (homogeneous) and a low value } \\
\text { indicates a dominance of partners from a diverse background (heterogeneous). }\end{array}$ \\
\hline $\begin{array}{l}\text { Spatial time- } \\
\text { distance of } \\
\text { partners }\end{array}$ & $\begin{array}{l}\text { Average travel time to partners by car (face-to-face meetings). A low value } \\
\text { indicates a short distance whereas a high value indicates a large distance. }\end{array}$ \\
\hline Mix of support & $\begin{array}{l}\text { A rank variable (1-4). This variable is calculated as the level of mix of conven- } \\
\text { tional (room, standard services and loan) and added-value support (e.g. customized } \\
\text { training of entrepreneurs), with rank 1 representing merely conventional support } \\
\text { and rank 4 representing conventional support and 60\% or more value added support. }\end{array}$ \\
\hline
\end{tabular}

*) Granovetter suggests that the strength of a relationship is a combination of various characteristics, like time spent in the relation, emotional intensity, and intimacy, etc. We were not able to measure the more emotional aspects (intensity and intimacy) directly but used proxies (frequency of interaction and duration of the relationship).

of the entrepreneurs into account. At technical universities, students and staff are trained to reduce uncertainty in experiments and measurement as much as possible, whereas as entrepreneurs they are facing a manifold uncertainty, residing in the technology, development of the market, finding adequate investment capital, etc. With regard to problems of market demand (11\%) some spin-offs turn out to be subject to a vicious circle in that they are not able to acquire a large customer, just because they had none before. This situation is generally known as the problem of market credibility [44]. Note that financial obstacles occur less frequently than market- and management obstacles (5 to $7 \%$ of all obstacles). This situation may be attributed to a combination of factors. Very often, at the start, family, friends and 'fools' provide start capital [38] whereas later on problems arise in attracting venture capital or a regular loan from banks, but Delft's spin-offs tend to solve this problem partially by self-financing. Previous research indicates that a substantial number of TU Delfts' spin-offs shift to a business model of self-financing by adding routine research or trade to their innovative activities [14]. Note that such a model solves financial problems but at the same time may introduce another, probably more critical problem, that is, a reduction of time and effort spent on the innovative product (process), potentially causing a lagging behind competitors.

In our exploration of determining factors of growth of TU Delft's spin-off firms, we used Ordinary Least Square (OLS) regression analysis. The way we measured the variables is 
Table 6. Results of the regression analysis

\begin{tabular}{|l|c|c|}
\hline \multirow{2}{*}{ Independent variables } & Model 1 & Model 2 \\
\cline { 2 - 3 } & $\beta$ & $\beta$ \\
\hline Socioeconomic network aspects & & $-.299^{* *}$ \\
\hline Tightness of relationships & $-.321^{* *}$ & $-.196^{*}$ \\
\hline Strength of relationships & $-.329^{*}$ & $-.258^{*}$ \\
\hline Homogeneity of network partners & $-.269^{* *}$ & $.405^{* *}$ \\
\hline Spatial distance of partners & $.442^{* *}$ & $.190^{*}$ \\
\hline $\begin{array}{l}\text { Support } \\
\text { Mix of support }\end{array}$ & & 20.59 \\
\hline F & 22.64 & 0.00 \\
\hline Significance of $\mathrm{F}($ Prob $<\mathrm{F})$ & 0.00 & 0.7462 \\
\hline $\mathrm{R}^{2}$ & 0.7155 & 0.7100 \\
\hline Adjusted $^{2}$ & 0.6839 & \\
\hline
\end{tabular}

$* p<0.10, * * p<0.05$

$N$ (spin-offs) $=51$

Source: Adapted from [15].

shown in Table 5 (see Appendix 1 for descriptive statistics). Two models were estimated. Model 1 deals with the influence of different socioeconomic aspects of knowledge networks, whereas Model 2 deals with the influence of these network aspects plus a single variable indicating the kind of mix of support types.

It appears that the beta-coefficients of all variables concerning the network characteristics and the mix of support are significant in the two models, in Model 1 mostly at the 0.05 level. The outcomes of Model 1 say that $72 \%$ of the variation in growth can be explained by different network characteristics. By adding the variable of mix of support, this increases to $75 \%$. By examining the signs of the beta coefficients, the following becomes clear. All three network characteristics that potentially exclude diversity in knowledge networks, like relations that are more tight, stronger and more homogeneous, all tend to negatively influence the growth of spin-offs. With regard to spatial proximity, the results point to a positive influence of relatively large distances between spin-offs and network partners. This contradicts the idea of benefits from local proximity, but confirms ideas of a negative influence of tightness based on a nearby location (like the negative influence of a more general tightness). With regard to the kind of support, the sign of the beta coefficient indicates that combinations with higher shares of value added support (not merely or mostly conventional support) tend to enhance growth (a positive sign).

We may conclude that in conformity with the results on growth of incubators, suggesting a positive influence of characteristics introducing diversity of resources to the incubator and to spin-offs, the results on growth of spin-off companies indicate a positive influence from socioeconomic network characteristics and from support that introduces diversity particularly in knowledge. 


\section{Concluding Remarks}

The empirical research of this study was carried out on two levels, i.e. incubators in various countries and spin-off companies in one particular region, viz. Delft in the Netherlands. Our findings on the first level suggest that fast growing incubators tend to be governed (initiated and managed) by a diversity of stakeholders, a situation that apparently introduces a relatively high diversity in resources disclosed by these networks. In addition, incubators in non-metropolitan (peripheral/rural) areas tend to grow more quickly than those in large metropolitan areas. This pattern points to more favorable conditions in nonmetropolitan areas, including benefits from national and/or EU policies. Overall, the combination of a differentiated stakeholder involvement and location in non-metropolitan areas turned out to produce the most powerful explanation of a relatively strong growth of incubators. In second place, but clearly less strong in explanation, was the combination of conventional support and a focused strategy of the incubators (merely research commercialization), leading to a relatively weak growth. What this broad picture makes clear is that aside from the location of the incubator, the institutional aspects of incubators as an outcome of Triple Helix processes tend to play a substantial role. Diversity and hybridization as indicated by modern Triple Helix concepts, manifest themselves in a mix of stakeholders and hybrid activity, a certain shift towards a profit-focused strategy giving access to limited numbers of start-ups "from outside", and extending conventional support with support through which entrepreneurs can improve their personal business capabilities. These findings may be helpful in designing future policies on technology incubators, in that incubator models reflecting diversity and hybridization tend to produce more dynamic developments. Note, however, that it remains to be seen to what extent diversity and hybridization produce positive results ; maybe there is an optimum, above which the impact becomes negative. In addition, a policy lesson for metropolitan areas may be that if university incubators are established these should be significantly different from existing accommodation for start-ups to prevent an over supply of the same kind.

Our results on the level of spin-off companies indicate that knowledge networks introducing diversity tend to have a positive impact on employment growth of spin-off companies; these are loose networks, weak networks, networks of partners with a strong heterogeneity in background and partners at a relatively large distance. The same holds for a balanced mix of conventional support and added value support (including a relatively high share of the latter). Like in the investigation of incubators, it could not be clarified in our study to what extent the knowledge networks need to inhibit the appropriate diversity characteristics and what the optimum situation is. Non-linearity may play a role. This brings us to future research. In order to identify a set of best diversity characteristics (or different sets of such characteristics) we recommend a cross-national comparative research of the growth of spin-offs from technical universities. In addition, it has remained unknown whether there is a difference in best diversity characteristics of knowledge networks between different contents of these networks, like investment capital, market opportunities, global research opportunities, etc. For example, it is quite well possible that knowledge concerning investment capital requires different networks in terms of tightness and strength compared 
with knowledge concerning market opportunities. This constitutes a second avenue for future research. Similarly, the role of age of spin-offs in determining the appropriateness of particular network characteristics has remained outside the current study but may be worth investigating in future research. Last but not least, the trend that spatial proximity in knowledge networks influences the growth rate of spin-offs negatively, calls for attention in future research. Our estimation results suggest that there may be other local influences at work than a particular set of socioeconomic characteristics of the networks.

\section{Notes}

1. We followed two steps in the application of rough set analysis. First, we reduced the base-sample of 40 incubators to 25 incubators by random sampling; the latter number can be handled more easily. To avoid sensitivity for random sampling we worked with 10 samples of this size. Secondly, we measured accuracy connected with the decision rules as a standard routine by ROSE2 and as an additional step to assess the prediction power of the decision rules, using samples not used before (prediction accuracy) (for an explanation see, [18]). The accuracy of the core attributes and of all attributes turned out to be 75 and $76 \%$ respectively, and the prediction accuracy amounted to $73 \%$. These levels could justify the use of the decision rules in our interpretation of the rough set results. Note that our analysis only included one-way relationships. Accordingly, we may have overlooked a part of the complexity, particularly feedback effects such as between growth of the incubator and stakeholders' involvement. However, in a relatively quick first causal analysis we need to limit our self to a simple model.

2. Delft University of Technology was founded in 1842 as the Royal Academy for military and civil engineers. In the course of history, the academy was transformed into a technical university and today (2005) it has more than 13.000 students. TU Delft is located in the medium-sized town of Delft (about 90.000 inhabitants), adjacent to the larger cities of The Hague and Rotterdam in the metropolitan area of the Randstad.

3. To check for multicollinearity, the so-called variance inflation factor (VIF) was used. High VIFs are an indication for the presence of multicollinearity. In the regression analysis, the VIFs found in the estimates ranged from 1.24 to 1.58 , meaning that no multicollinearity problems occurred.

\section{References}

[1] Armstrong, H. and Taylor, J., Regional Economics and Policy, Oxford, Blackwell Publishers, 3rd edition, 2000.

[2] Audretsch, D.B., "Agglomeration and the Location of Innovative Activity," Oxford Review of Economic Policy, Vol. 14, 1998, pp. 18-29.

[ 3 ] B $\phi 1 l$ lingtoft, A. and Ulh $\phi$ i, J.P., "The networked business incubator - leveraging entrepreneurial agency?," Journal of Business Venturing, Vol. 20, 2005, pp. 265-290.

[4] Camagni, R., "Local Milieu, Uncertainty and Innovation Networks: Towards a Dynamic Theory of Economic Space," in : Camagni, R., (Ed.), Innovation Networks : Spatial Perspectives, pp. 121144. London: Belhaven Press, 1991.

[ 5 ] Castells, M. and Hall, P., Technopoles of the World. London, Routledge, 1994.

[6 ] Charles, D.R., "Universities and territorial development: reshaping the regional role of of English universities," Local Economy, Vol. 18, 2003, pp. 7-20.

[ 7 ] Charles, D. and Howells, J., Technology Transfer in Europe: Public and Private Networks, London, Belhaven Press, 1992.

[8 ] Coleman, J.S., Foundations of Social Theories, Cambridge, MA : Harvard University Press, 1990.

[9] Druilhe, C. and Garnsey, E., "Do Academic Spin-Outs Differ and Does it Matter?," Journal of 
Technology Transfer, Vol. 29, 2004, pp. 269-285.

[10] Etzkovitz, H., "Incubation of incubators: innovation as a triple helix of university-industrygovernment networks," Science and Public Policy, Vol. 29, 2002, pp. 115-128.

[11] Feldmann, M., "The New Economics of Innovation, Spillovers and Agglomeration,” Economics of Innovation and New Technology, Vol. 8, 1999, pp. 5-25.

[12] Florida R., "The economic geography of talent," Annals of the Association of American Geographers, Vol. 92, 2002, pp. 743-755.

[13] Geenhuizen, M. van, "How can we reap the fruits of academic research in biotechnology? In search of critical success factors in policies for new-firm formation.” Environment and Planning C, Vol. 21, 2003, pp. 139-155.

[14] Geenhuizen, M. van and Soetanto, D.P., “Academic Knowledge and Fostering Entrepreneurship : An Evolutionary Perspective”. In : Groot, H. Nijkamp, P. and R. Stough (eds) Entrepreneurship in the Modern Space-Economy : Evolutionary and Policy Perspectives. London, Edward Elgar, 2004, pp. 252-268.

[15] Geenhuizen, M. van and Soetanto, D.P., "How Networks and Support May Remove Bottlenecks in Growth of University Spin-offs : The Case of Delft University of Technology," in : Markowski, T. (ed) High-Tech Marketing and Territorial Growth. Warsaw, Polish Academy of Science (in press), 2007.

[16] Gibbons, M., Limoges, C., Nowotny, H., Schwartzman, S., Scott, P. and Trow, M., The new production of knowledge. The dynamics of science and research in contemporary societies, London, Sage, 1994.

[17] Glaeser, E.L., Kolko, J. and Sainz, A., “Consumer city,” Journal of Economic Geography, Vol. 1, 2001, pp. 27-50.

[18] Goh, C. and Law, R., "Incorporating the Rough Sets Theory Into Travel Demand Analysis," Tourism Management, Vol. 24, 2003, pp. 511-517.

[19] Granovetter, M., “The Strength of Weak Ties,” American Journal of Sociology, Vol. 78, No. 6, 1973, pp. $1360-1380$.

[20] Hackett, S.M. and Dilts, D.M., “A Systematic Review of Business Incubation Research,” Journal of Technology Transfer, Vol. 29, 2004, pp. 55-82.

[21] Hannon, P.D. and Chaplin, P., "Are incubators good for business? Understanding incubation practice - the challenges for policy," Environment and Planning C: Government and Policy, Vol. 21, 2003, pp. 861-881.

[22] Hansen, M.T., Chesbrough, H.W., Nohria, N. and Sull, D.N., "Networked incubators. Hothouses of the new economy," Harvard Business Review, Vol. 78, No. 5, 2000, pp. 74-84.

[23] Hofstede, G., Culture and Organizations : Software of the Mind, British Library, London, 1991.

[24] Jacobs, J., The death and life of great American cities. Random House, New York, 1961.

[25] Keeble, D., Lawson, C., Moore, B., Wilkinson, F., "Collective Learning Processes, Networking and 'institutional thickness' in the Cambridge Region,” Regional Studies, Vol. 33, 1999, pp. 319-332.

[26] Kenney, M., Biotechnology, Yale University Press, New Haven, 1986.

[27] Leydesdorff, L., "A Methodological Perspective on the Evaluation of the Promotion of UniversityIndustry-Government Relations," Small Business Economics, Vol. 20, 2003, pp. 201-204.

[28] Marsden, P.V. and Campbel, K.E., "Measuring Tie Strength,” Social Forces, Vol. 63, No. 2, 1984, pp. 482-501.

[29] Maskell, P. and Malmberg, A., "Localised learning and industrial competitiveness," Cambridge Journal of Economics, Vol. 25, 1999, pp. 167-185.

[30] McEvily and Zaheer, A., "Bridging ties: A source of firm heterogeneity in competitive capabilities," Strategic Management Journal, Vol. 20, 1999, pp. 1133-1156.

[31] McKinnon, S and Hayhow, S., State of Business Incubation Industry, National Business Incubator Association (NBIA), Ohio, 1998. 
[32] Monck, C.S.P., Porter, R.B., Quintas, P., Storey, D.J. and Wynarczyk, P., Science Parks and the Growth of High Technology Firms. Croom Helm, London, 1988.

[33] Nijkamp, P., Rodenburg, C.A. and Wagendonk, A.J., "Success factors for Sustaining Urban Brownfield Development: A comparative case study approach to polluted sites," Ecological Economics, Vol. 40, 2002, pp. 235-252.

[34] Nijkamp P., Burch M. van der, Vindigni, G., "A comparative institutional evaluation of publicprivate partnerships in Dutch Urban land-use and revitalization projects," Urban Studies, Vol. 39, 2002, pp. $1865-1880$.

[35] Nowotny, H., Scott, P. and Gibbons, M., Re-Thinking Science. Knowledge and the Public in an Age of Uncertainty. Cambridge: Polity Press, 2001.

[36] Pawlak, Z., Rough sets: Theoretical Aspects and Reasoning About Data, Kluwer Academic, Dordrecht, The Netherlands, 1991.

[37] Predki, B., and Wilk, S., "Rough Sets Based Data Exploration using ROSE system". In : Ras, Z.W., Skowron, A. (eds.), Foundation of Intelligent Systems. Lecture Notes in Artificial Intelligence 1609, Springer, Berlin, 1999.

[38] Roberts, E.B., Entrepreneurs in high-technology. Lessons from MIT and beyond. New York: Oxford University Press, 1991.

[39] Rowley, T., Behrens, D. and Krackhardt, D., "Redundant Governance Structure: An analysis of structural and relational embeddedness in the steel and semiconductor industries," Strategic Management Journal, Vol. 21, 2000, pp. 269-386.

[40] Saxenian, A., Regional Advantage, Harvard University Press, Cambridge, Mass, 1994.

[41] Scholten, V., The early growth of academic spin-offs: Factors influencing the early growth of Dutch spin-offs in the life-sciences, ICT and consulting, PhD dissertation, Wageningen University, The Netherlands, 2006.

[42] Shane, S., Academic Entrepreneurship: University Spinoffs and Wealth Creation, Edward Elgar, Cheltenham, 2004.

[43] Smilor, R.W., Gibson, D.V. and Kozmetsky, G., "Creating the Technopolis: High Technology Development in Austin, Texas," Journal of Business Venturing, Vol. 4, 1988, pp. 49-67.

[44] Soetanto, D. and Geenhuizen, M. van., "University Spin-offs at Different Ages: In Search of Obstacles to Better Match Support," in : Groen, A., R. Oakey, P. vd Sijde and S. Kauser (eds) New Technology Based Firms in the New Millenium, V, Amsterdam: Elsevier, 2006, pp. 23-37.

[45] Soetanto, D. and Geenhuizen, M. van., "Technology Incubators and Knowledge Networks. A Rough-set Approach in Comparative Project Analysis," Environment and Planning B (Planning and Design) (in press), 2007.

[46] Ubbels, B. and Nijkamp, P., "Unconventional funding of urban public transport," Transportation Research Part D, Vol. 7, 2002, pp. 317-329.

[47] Uzzi, B., "The Sources of Consequences of Embeddedness for the Economic Performance of Organizations: the Network Effects," American Sociological Review, Vol. 61, 1996, pp. 674-698.

[48] Viale, R. and Etzkowitz, H., "Third Academic Revolution: Polyvalent Knowledge: the "DNA" of the Triple Helix," Presentation at the 5th Triple Helix Conference, The Capitalization of Knowledge, May 18-21 2005, Fondazione Rosselli, Turino, Italy, 2005. 
Appendix 1

Descriptive statistics

\begin{tabular}{|l|l|c|}
\hline & \multicolumn{1}{|c|}{ Mean } & S.D \\
\hline Dependent variable & & \\
\hline Job growth (1996-2005) & 1.1 (fte) & 1.0 \\
\hline Independent variables & 0.27 & 0.20 \\
\hline Characteristics of knowledge networks (2005) & 4.36 \\
\hline Tightness of relationships & 8.13 & 0.13 \\
Strength of relationships & 0.58 & 8.05 \\
Homogeneity of networks partners & 20.01 (minutes by car) \\
Spatial distance of partners & \multicolumn{2}{|l}{} \\
\hline Type of support & 2.58 & 0.80 \\
\hline Mix of support & \multicolumn{2}{|l}{} \\
\hline
\end{tabular}

